\title{
Controller en business partner
}

Arco van de Ven

SAMENVATTING De oproep aan controllers om meer als business partner te opereren is niet nieuw. Waarom zijn controllers na al die jaren geen business partners? Uitkomsten van wetenschappelijk onderzoek laten zien dat de normatieve oproep om business partner te worden geen rekening houdt met de complexiteit die de rol van controllers in de praktijk bepaalt. Het lijkt wenselijk om meer aandacht te besteden aan de factoren die de ontwikkeling tot business partner in de praktijk bemoeilijken en om de verschillende mogelijke invullingen en de grenzen van het optreden als business partner te onderzoeken.

RELEVANTIE VOOR DE PRAKTIJK Wetenschappelijk onderzoek laat zien dat alhoewel de wens om business partner te zijn zeker niet nieuw is, er weinig aanwijzingen zijn dat deze ambitie wordt gerealiseerd. Het artikel biedt op basis van uitkomsten van wetenschappelijk onderzoek inzicht in de bepalende factoren voor de rol die controllers in organisaties vervullen.

\section{Inleiding}

'Yet early findings from the independent research which CIMA has commissioned suggests that despite much rhetoric about business partnering, in most organizations there has not been a stepped change in the role of finance' (CIMA, 2009, p. 5).

Controllers moeten business partners worden! Deze uitspraak is het laatste decennium vaak te lezen in vaktijdschriften (Russell et al, 1999; Johnsson, 2002; Sinnett, 2007; Kolthof \& Lemstra, 2008; Davis \& McLaughlin, 2009, Te Woerd, 2009) en wordt breed uitgedragen door adviesbureaus (CFO Research Services, 2002; Accenture, 2008; IBM, 2010). Maar worden controllers ook inderdaad business partners? In dit artikel $^{1}$ zal worden ingegaan op wat er vanuit wetenschappelijk onderzoek bekend is over de controller en business partnership in organisaties. Gestart wordt met de vraag of het streven naar de rol van business partner nieuw is en of een ontwikkeling naar business partner wenselijk is. Vervolgens wordt op verschillende mogelijke oorzaken van de afwijking van de werkelijke controllersrol van de gepropageerde business partner ingegaan. Ten eerste kan de business partnerrol verschillend worden gedefinieerd; ten tweede zijn er diverse factoren die de wijze waarop individuele controllers in organisaties hun rol invullen kunnen verklaren.
Ten derde zijn er verschillende wijzen van totstandkoming van de invulling van de controllingafdeling binnen organisaties. Tot slot is er een mogelijk moeizame en potentieel negatieve wisselwerking van de verantwoordelijkheid van de controller als bedrijfseconomisch geweten met de verantwoordelijkheid van business partner. Het artikel wordt afgesloten met conclusies over de praktijk van het controllership en met suggesties voor toekomstig onderzoek.

\section{Business partner?}

De stelling dat controllers business partners moeten worden lijkt gemeengoed te zijn. Wie 'controller en business partner' googled krijgt bijna honderd miljoen hits ${ }^{2}$. In het aanbod aan cursussen, gouden tips, weblogs, vacatures, artikelen en onderzoeksrapporten wordt het belang van de controller als business partner naar voren gebracht. Dit roept de vraag op of de rol van controller echt aan het veranderen is. Het vak, de naam 'controller' en wetenschappelijk onderzoek rond de functie van de controller heeft al een lange geschiedenis. In 1928 werd door Kester (1928) een empirisch onderzoek onder de titel 'The importance of the controller' in The Accounting Review gepubliceerd $^{3}$. Controllership wordt door Kester (1928, p. 242) gedefinieerd als: 'that function whose responsibility it is to measure the efficiency of the operating executives, report findings, and suggest policies or remedies'. Controllers hadden volgens Kester niet alleen een uitvoerende taak maar waren ook in een betere positie om gegevens te interpreteren dan anderen binnen de organisatie (Kester, 1928, p. 245). Dus in 1928 was adviseren door middel van het interpreteren en rapporteren van bevindingen een belangrijk element in de taakuitvoering van controllers. Empirisch onderzoek van Nobelprijswinnaar Herbert A. Simon en collega's uit 1954 laat een zelfde beeld zien. De doelstelling voor controllers wordt door hen als volgt ingevuld: a) het leveren van informatiediensten van hoogwaardige kwaliteit; b) tegen minimale kosten; en c) het faciliteren van de langetermijnontwikkeling van deskundige financiële en operationele managers (Simon et al. 1954, p. vi).

Door de vele handmatige activiteiten lag de nadruk op de uitvoerende activiteiten die nodig waren voor het systematisch verzamelen en verwerken van gegevens. Het verstrekken van betrouwbare informatie staat in relatie tot de vertrouwensrol van de controller (Maas, 2005; Merchant \& Van der Stede 2007, p. 640). Naast deze ver- 
trouwensrol wordt door Merchant en Van der Stede ook nog de toezichtsrol en management servicerol benoemd. In de toezichtsrol bewaakt de controller het algemene belang van de organisatie. Houden medewerkers zich aan de vigerende interne en externe regelgeving? Vaak worden de vertrouwensrol en de toezichtsrol gecombineerd aangeduid als de controlerende rol van de controller. Bij de management servicerol, vaak ook adviesrol genoemd, gaat het erom het management bij te staan en te adviseren bij de operationele en strategische besluitvorming. In de begindagen kwam dit adviseren neer op het verstrekken van relevante informatie, waarbij aandacht werd besteed aan het creëren van een referentiekader waartegen de informatie over de werkelijkheid kon worden afgezet. Vandaar dat in die dagen in het takenpakket van de controller een grote mate van aandacht is voor het planningsproces en voor het interpreteren en rapporteren van afwijkingen van het jaarplan.

Maar staat het interpreteren en rapporteren gelijk aan het vervullen van de business partnerrol? In 1963 heeft Stanley Harding, deputy controller van Shell, een lezing gehouden onder de titel 'Increased productivity - the role of finance' waarin hij de noodzaak aangeeft dat financiële managers 'an active (not a non-playing) member of the management team' moeten zijn (Harding, $1963 / 2013$, paragraaf 17). Harding stelt in relatie tot de opleiding van controllers dat 'we should be more appreciated if we train our young men and encourage those already qualified (whether in the profession or industry) to act as business men with a responsibility to increase the efficiency and productivity of the business with which they are in contact, and looking more to the future than to the past' (Harding, 1963/2013, paragraaf 102). Waar de functie van controller in de beginjaren draaide om het leveren van hoogwaardige ex post informatie, is volgens Harding voor het bereiken van meer efficiency meer nodig dan alleen rapporteren. Controllers moeten naar zijn mening actieve leden zijn van het managementteam. Ook Sathe stelt in 1983 dat het verstrekken van informatie niet voldoende is. De controller moet het management adviseren. Het beschikbaar stellen van informatie wil niet zeggen dat de informatie tot zijn recht komt en op een juiste manier in de besluitvorming wordt betrokken. Om dit te bereiken moet de controller volgens Sathe actief deelnemen aan het besluitvormingsproces, richting geven aan de activiteiten en voorstellen van operationele managers kritisch benaderen (Sathe, 1983, p. 32).

Uit de voorbeelden van Harding uit 1963 en Sathe uit 1983 blijkt dat de boodschap dat controllers bij het uitvoeren van de adviesrol meer als partner van de business moeten functioneren niet echt nieuw is. Baldsvindottir et al. (2013) concluderen op basis van interviews met management accountants van de laatste dertig jaar: 'thus, being a business partner may not be as new as currently suggested. In the recordings from the 1980s and 90s we have stories of accountants who were seeking, and sometimes struggling due to the lack of the necessary resources, to provide business support and to be a part of the decision-making in their organizations' (Baldsvindottir et al., 2013, p. 52).

\section{Adviesfunctie}

De vraag die dit oproept is waarom na vijftig jaar nog steeds het geluid klinkt dat controllers meer de business partnerrol moeten oppakken. Waarom is dit al niet gerealiseerd? Is het inderdaad wel zo waardevol voor organisaties en/of zijn er problemen die het doorvoeren van een dergelijke verandering blokkeren?

Dat betrokkenheid bij besluitvorming waarde kan toevoegen, blijkt uit onderzoek van Zoni en Merchant (2007). Zij hebben bij 17 industriële bedrijven in Italië de betrokkenheid van controllers bij de strategische en operationele besluitvorming onderzocht. Bij deze groep van bedrijven was de betrokkenheid van de controllers significant positief gecorreleerd met de winstgroei over de laatste vijf jaar. Het onderzoek ondersteunt derhalve de veronderstelling dat betrokkenheid van controllers een positief effect op het bedrijfsresultaat kan hebben. Maar betrokkenheid bij de strategische en operationele besluitvorming zegt nog niets over hoe controllers invulling aan deze betrokkenheid geven.

Wat weten we over hoe de adviesfunctie in de rol van business partner moet worden ingevuld? Gebaseerd op de wens en verwachting van controllers in de praktijk wordt benadrukt dat de controller zich meer zou moeten gaan richten op waarde-toevoegende activiteiten. Een enquête uit 1999 getiteld Counting more, counting less onder de beroepsgroep in de Verenigde Staten geeft aan dat er minder (ac)counting zou moeten plaatsvinden om meer waarde toe te voegen. Als meest kritische factor om dit te bereiken wordt betrokkenheid bij strategische planning en procesverbeteringen genoemd (Russell, 1999). Het rapport was nog van vóór de internetcrisis die in 2000 uitbrak en van vóór de teloorgang van Enron. Maar het begrip 'waardecreatie' is het woord dat ook na de boekhoudfraudes steeds meer in verband wordt gebracht met de controllerfunctie. Het terugdringen van kosten van de transactieverwerking moet gepaard gaan met het verhogen van de effectiviteit van besluitvorming en met een hogere bijdrage aan strategievorming (CFO Research Services 2002, p. 2; IBM 2010). Interviews met controllers door Ernst \& Young (2008, p. 4) geven aan dat veranderende rapportages van belang zijn. Waardetoevoeging moet plaatsvinden door scores op niet-financiële indicatoren te rapporteren, rapportages elektronisch te verstrekken, meer waarde- toevoegend commentaar te geven en de nadruk te leggen op relevantie en bondigheid. Zo bena- 
drukt 'Accenture' dat controllers leiderschap moeten tonen: '[i]t is the finance organization that must take a leadership role in driving the enterprise towards continuing value creation ensuring the enterprise possesses the strategies, capabilities and information to succeed in the hypercompetitive global market even as it continues to control and maintain costs' (Accenture 2008 , p. 3). Een rapport van IBM gebaseerd op een enquête onder 1900 CFO's pleit tevens voor waardetoevoeging als 'value integrator'. De controller is in staat om in de organisatie brede inzichten op te doen, die moeilijk te zien zijn vanuit de functionele invalshoeken van de verschillende afdelingen (IBM 2010, p. 50).

De nadruk op strategische waardecreatie leidt in sommige publicaties tot een pleidooi dat controllers zich niet moeten beperken tot het ondersteunen van de besluitvorming. $\mathrm{Zij}$ moeten een vergaande vorm van verantwoordelijkheid voor de besluitvorming nemen. Auteurs zoals Chui en Curtis (2010) geven aan dat controllers meer ondernemend moeten worden. Zij moeten zelf verantwoordelijkheid nemen en risico's aangaan door bijvoorbeeld nieuwe innovatieve concepten te adopteren en te implementeren.

Deze besproken enquêtes van de adviesbureaus en artikelen vanuit de praktijk zijn gericht op welke rol controllers zouden moeten vervullen. De enquêtes bijvoorbeeld beschrijven niet zo zeer dat wat controllers in de praktijk doen maar meer wat ze zouden moeten doen. De validiteit van de conclusies en aanbevelingen is hierdoor beperkt. De vraag is of controllers in de toekomst ook daadwerkelijk zo gaan acteren. Is er inderdaad sprake van een hogere mate van betrokkenheid bij strategievorming en procesoptimalisatie? En gaan controllers een meer dan ondersteunende rol bij de besluitvorming spelen zoals Chui en Curtis (2010) voorstellen? Met uiteindelijk als belangrijkste vraag of deze veranderende rol van de controller dan ook gaat leiden tot de beoogde waardetoevoeging. Empirisch onderzoek laat tot op heden deze beweging niet echt zien (CIMA, 2009, p. 5; Van de Ven, 2011; Van Veen-Dirks, 2012, p. 21). In 2004, 2007 en 2010 heeft de Open Universiteit in samenwerking met andere universiteiten onderzoek verricht onder afgestudeerden van de Registercontroller- en Financial Controller-opleidingen. Uit de controllerenquêtes van 2003 en 2007 blijkt niet direct dat er in Nederland een duidelijke verschuiving is te onderkennen. Er waren geen groepen controllers die werden gekenmerkt door een leidende of ondersteunende rol in strategieformulering. De eerste resultaten van het onderzoek uit 2010 geven wel een type controller (61\% van de respondenten) aan dat zich mede kenmerkt door betrokkenheid bij strategische planning. Of deze betrokkenheid wordt veroorzaakt omdat controllers meer betrokken worden bij het formuleren van de strategie is de vraag. Het on- derzoek laat zien dat er door de financiële crisis meer gedetailleerde budgettering heeft plaatsgevonden ten behoeve van de planning van cash-flows, om kosten te duiden en ten behoeve van planning van de financiële positie (Van Veen-Dirks en De Loo, 2011, p. 217). Betrokkenheid bij strategievorming kan derhalve goed inhouden een hoge mate van ondersteuning door gedetailleerde budgettering. In tegenstelling met het rapport 'Counting more, counting less' (Russell et al., 1999) dus niet minder, maar dus meer (ac)counting! Hoe deze betrokkenheid wordt ingevuld door controllers en of controllers daadwerkelijk meer leiderschap vertonen en de organisatie aanzetten tot waardecreatie blijft de vraag. Wetenschappelijk onderzoek bevestigt tot op heden niet de verwachtingen van een vergaande transitie van de controller naar business partner.

\section{Verschillen tussen controllers}

De roep om business partner te worden lijkt gebaseerd te zijn op de veronderstelling dat onafhankelijk van de omstandigheden controllers op een zelfde wijze zouden moeten opereren. Om inzicht te geven in de problemen die met het invullen van de adviesfunctie gepaard kunnen gaan, is het goed om inzicht te hebben in wat controllers in de praktijk doen en in hoeverre er sprake is van verschillende soorten controllers. Er is veel wetenschappelijk onderzoek gepleegd naar de verschillende rollen die controllers in de praktijk vervullen. Wetenschappelijk onderzoek suggereert dat verschillende omstandigheden er toe leiden dat er verschillen tussen controllers voorkomen. Onderzoek van Sathe in de tachtiger jaren geeft aan dat verschil in het belang van de adviesrol en de controlerende rol kan leiden tot diverse soorten controllers. Een meer betrokken controller wanneer de adviesrol sterk wordt ingevuld, een onafhankelijke controller wanneer de nadruk op de controlerende rol ligt en een sterke (strong) controller wanneer de rollen worden gecombineerd. Daarnaast onderkent hij de zogenaamde 'split-controller' wanneer in een afdeling de advieswerkzaamheden worden afgesplitst van de controlewerkzaamheden (Sathe 1983). Dit zou betekenen dat er binnen de controllerafdeling twee soorten controllers bestaan. Uit casusonderzoek van Burns \& Baldvinsdottir (2005) komt een andere mogelijke ontwikkeling van de controllerrol naar voren, een ontwikkeling die leidt tot de hybride controller. Deze controller verricht zowel advies- als controlewerkzaamheden. De specifieke omstandigheden in de organisatie bepalen welke rol wordt ingevuld. Dus een 'strong controller' is niet de universele norm; het type controller is situationeel bepaald.

Empirische onderzoeken in Nederland laten verschillende invullingen van de functie van controller zien. Het al eerder genoemde onderzoek van de verschillende controllerenquêtes in 2003, 2007 en 2010 laat zien dat er in Nederland inderdaad (twee) verschillende groepen van con- 
trollers zijn te onderkennen. Er is een ontwikkeling zichtbaar, want over de jaren heen veranderen de activiteiten die deze typen van controllers verrichten. Deze verschillende typen controllers zijn echter niet gelijk aan de ideaaltypen van de betrokken of onafhankelijke controller van Sathe. In 2004 werd door Verstegen et al. een type controller onderkend die zij 'watchmen' hebben genoemd. De 'watchmen' richten zich met name op het beheren en onderhouden van administratieve systemen en het monitoren van risico's. Het andere type, 'information adapters', had als gezamenlijke activiteiten het ontwerpen en veranderen van beheersingssystemen, het ondersteunen van veranderprocessen en de interne en externe verslaggeving (Verstegen et al., 2007, p. 15). In 2007 werden er ook twee typen controllers geïdentificeerd (De Loo et al, 2011). Deze typen hadden een overlap aan activiteiten. Beide typen verrichtten activiteiten op het gebied van interne analyse en risicomanagement. Het type door de auteurs 'reporting business analyst' genoemd, hield zich bezig met interne en externe verslaggeving en het type 'business system analysts' kenmerkte zich door de gezamenlijke activiteit van het onderhoud van administratieve systemen (De Loo et al., 2011, p. 293-294). Ook in 2010 zijn er twee typen controllers gevonden, die geen naam mee hebben gekregen. Er is een type controllers dat zich met name bezighoudt met strategische planning, formele interne rapportage en externe belangenbehartiging. Het andere type houdt zich bezig met verandermanagement en het onderhoud van management controlsystemen (Van Veen-Dirks \& De Loo, 2011, p. 214).

Over de jaren heen zijn er dus twee typen controllers gevonden die activiteiten verrichten die zich richten op verandermanagement en het ontwerpen, veranderen en onderhouden van systemen en activiteiten gericht op rapportage en analyse. In de eerste controllerenquêtes was er een overlap en had de controller die belast was met rapportage en analyse ook activiteiten die gerelateerd waren aan het veranderen van de systemen. In de laatste enquête lijkt er een specialisatie op te treden van controllers die meer gericht zijn op activiteiten gerelateerd aan systemen en controllers die meer bezig zijn met rapportages en analyses. De relatie met aandacht vanuit verschillende vakgebieden ligt voor de hand. Een type controllers waarbij de administratieve organisatie centraal staat versus controllers waarbij management accounting en control de belangrijkste rol speelt ${ }^{4}$. De vraag is hoe dit valt te relateren aan het pleidooi voor een ontwikkeling van de controller als business partner met meer aandacht voor strategie en procesoptimalisatie? De laatste controllerenquête suggereert dat aandacht voor strategie wellicht door een ander type controllers zal worden ingevuld dan controllers die aandacht besteden aan procesoptimalisatie. De wijze waarop controllers functioneren en invulling geven aan de adviserende en controlerende rol zal voor de twee typen controllers verschillend zijn.
Nu het duidelijk is dat de functie van controller verschillend wordt ingevuld, is de vervolgvraag welke factoren bepalend zijn op welke wijze de functie wordt ingevuld. Het aangehaalde Italiaanse onderzoek van Zoni en Merchant (2007) geeft aan dat de factoren die bepalend zijn voor de betrokkenheid van controllers bij de strategische besluitvorming verschillen van die voor betrokkenheid bij de operationele besluitvorming. De betrokkenheid van de controllers bij de strategische besluitvorming was hoger bij een hogere mate van financiële kennis van het lijnmanagement, een hogere mate van kapitaalsintensiviteit en een hogere mate van formele strategische planning. De onderzoekers hadden verwacht dat juist een lager financieel kennisniveau van de lijnmanagers tot meer betrokkenheid van de controllers bij de formele strategische planning zou leiden. De toegevoegde waarde van de controllers zou dan immers groter zijn. Maar het niet onderkennen en waarderen van financiële kennis door het lijnmanagement kan een beperkende factor zijn die de invoering van de business partnerrol beperkt.

De betrokkenheid bij het operationeel management was sterker indien er een hoge mate van onderlinge afhankelijkheid tussen organisatieonderdelen was, hetgeen in lijn is met het denkbeeld dat controllers waarde kunnen toevoegen door procesoptimalisatie als 'value integrator' (IBM, 2010, p. 50). De betrokkenheid is zwakker indien de controllerfunctie als een traineeship voor lijnfuncties werd gebruikt. Ook dit hadden de onderzoekers op voorhand niet verwacht. Wellicht dat de status van de controller te lijden heeft onder de traineefunctie.

De Nederlandse controllerenquêtes van 2003 en 2007 laten over de jaren heen verschillende typen 'triggers' zien die gerelateerd zijn aan de rol van de controller.

Ten eerste kunnen omgevingsfactoren door de jaren heen verschillen. In 2003 is de relatief sterke ontwikkeling in ICT gerelateerd aan de meer advies-georiënteerde rol, in 2007 is een toename in wet- en regelgeving gerelateerd aan de minder advies-georiënteerde rol. Met name dat veranderende wet- en regelgeving de toezichtsrol van controllers belangrijker heeft gemaakt, lijkt aannemelijk. Wellicht heeft dat anderzijds beperkend gewerkt op het belangrijker maken van de business partnerrol.

Ten tweede zijn er factoren te onderkennen die samenhangen met de organisatie, zoals omvang (controllerenquête 2003 en 2007). Hoe groter de organisatie des te minder controllers adviserend optreden. In 2007 leidde de intensiteit van financiële problemen tot een meer advies-gerelateerde rol. Dat er in economisch zware tijden meer behoefte is aan financiële kennis lijkt inderdaad voor de hand te liggen. Of dit ook leidt tot meer nadruk op toegevoegde waarde, op betrokkenheid bij strategie en procesinnovaties, valt te bezien. 
Het is goed mogelijk dat dit leidt tot een striktere financiële bewaking met meer aandacht voor budgettering en forecasting, zoals uit de controllerenquête van 2010 blijkt (Van Veen-Dirks \& De Loo, 2011, p. 215).

Ten derde is het opvallend dat aan de persoon gekoppelde factoren een belangrijke rol spelen. Het aantal jaren ervaring, karaktereigenschappen zoals het extravert of introvert zijn (controllerenquête 2003) en de hoedanigheid van een doener dan wel een denker zijn van invloed. Ook het geslacht speelt een rol, vrouwelijke controllers (controllerenquête 2007) zijn meer gericht op een adviserende rol. Al in 1983 benadrukte Sathe (1983) het belang van specifieke competenties die nodig zijn om de rol van 'strong controller' in te vullen. Maar gegeven de vraag wat mogelijkerwijs de invoering van de business partnerrol negatief kan beïnloeden, is het denkbaar dat niet zozeer de situatie de rol van de controller bepaalt, maar dat de rol vooral door de persoonlijke eigenschappen van de controller wordt bepaald.

Wat is er vanuit onderzoek bekend over de persoonlijke typen en beroepsgroepen? Er is een toename aan aandacht voor bepaalde 'cognitieve stijlen' waarmee individuen 'perceive, think and solve problems, learn, take decisions and relate to others' (Witkin et al., 1977 geciteerd in Amstrong et al., 2012, p. 238). De laatste veertig jaar is er veel managementonderzoek verricht naar de rol van cognitieve stijlen (Armstrong, 2012). Onderzoek onder accountants en auditors is voornamelijk gebaseerd op de Myer-Briggs Type Indicator (MBTI, het populaire instrument dat is afgeleid van de theorieën van Carl Jung). Een overzicht van deze onderzoeken wordt gegeven door Briggs et al. (2007). Het dominante persoonlijkheidstype van accountingstudenten en accountingprofessionals is de STJ-stijl (Sensing, Thinking en Judging) (Briggs et al., 2007). 'Sensing' draait om een stijl waarbij de wereld wordt gezien als een geheel van feiten en waarbij details een grote rol spelen. 'Thinking' slaat op een rationele benadering van besluitvorming en 'judging' betekent dat wanneer er eenmaal een beslissing is genomen, deze niet lichtvaardig zal worden teruggedraaid. In de tegenovergestelde persoonlijke stijl IFP (Intuition, Feeling en Perceiving) draait het bij intuitieve types meer om de ideeën en om het verkrijgen van overzicht; details zijn van minder belang. Gevoelens en waarden spelen een belangrijkere rol in de besluitvorming ('feeling') en de persoon staat meer open voor nieuwe ontwikkelingen en alternatieve mogelijkheden. De vraag is of het daadwerkelijk optreden als business partner niet een meer intuitieve stijl vereist, waarbij overzicht belangrijker gaat worden dan de details. En of bij toenemende onzekerheid een 'perceiving' stijl juist belangrijker gaat worden. Briggs en collega's (2007, p. 528) concluderen dat de persoonlijkheidsstijlen in de 'accounting profession' de laatste twintig jaar niet significant zijn veran- derd. Een mogelijke verklaring wordt door Holland (geciteerd in Bradley-Geist et al., 2012, p. 151) gegeven: 'if a person enters a given vocation because of a particular personality and history, it follows that each vocation attracts people with similar personalities.' Het is dus goed mogelijk dat de beroepsgroep van controllers mensen met een 'afwijkende' IFP-stijl niet echt aantrekt. Dat is een belangrijk punt, zeker tegen de achtergrond van het onderzoeksgegeven dat het aantal jaren ervaring zeer belangrijk is voor het vervullen van de meer adviserende rol. Onderzoek onder controllers naar de relatie tussen de business partnerrol en persoonlijke eigenschappen kan hierbij belangrijke inzichten opleveren.

Onderzoek naar controllerrollen en naar de samenhang van activiteiten die individuele controllers vervullen, laat zien dat er verschillende typen controllers bestaan. Controllers die zich meer op de administratieve systemen richten en controllers die meer bezig zijn met rapportage. De vraag is of het ook wenselijk is dat de beide groepen zich zouden moeten ontwikkelen naar verschillende typen van business partners.

\section{Verschillen tussen controllingafdelingen}

Bij de discussie over de business partnerrol wordt vaak direct aan de persoonlijke invulling van een takenpakket van de controller gedacht. Zo is de controllerenquête uitgezet onder individuele controllers. De specifieke organisatorische context wordt hierdoor buiten beschouwing gehouden. Een aantal wetenschappelijke onderzoeken kijkt nu juist wel naar deze organisatorische context. Zo heeft Mouritsen (1996) een enquête uitgezet onder alleen eindverantwoordelijke managers van financiële afdelingen in Denemarken. Hij heeft vijf verschillende type afdelingen gevonden, te weten: boekhouden, consulting, bankieren, controlling en (werkkapitaal)beheer. Bij afdelingen getypeerd als 'boekhouden' staat het verwerken van transacties centraal. 'Consulting' sluit aan bij de business partnerrol, waarbij de nadruk ligt op ad-hoc analyses voor besluitvorming. Bij 'bankieren' ligt de nadruk op financieringskwesties en complexere kasstroombeheersing. Bij 'controlling' draait het om planning en control en het bewaken van budgetten. En tot slot staat 'cash-management' centraal bij de beheerafdeling. Het onderzoek van Mouritsen suggereert dat er verschillende 'configuraties' zijn voor de financiële functie. Hij geeft aan dat er geen externe bepalende factoren zijn, maar dat de vormgeving van de functie wordt bepaald door interne processen binnen de organisatie. Niet externe omstandigheden bepalen hoe de functie er uitziet, maar interactie met andere medewerkers van andere afdelingen bepaalt de uiteindelijke vorm.

De invloed van de relaties met andere professionals is iets wat veelal niet naar voren komt in de normatieve roep om van controllers business partners te maken. Onderzoek 
van Ezzamel en Burns (2005) beschrijft competitie tussen financiële managers en inkopers en 'merchandisers' in een grootwinkelorganisatie. Een verhaal van weerstand en machtsstrijd tussen verschillende professies. De enquêtes van IBM, Accenture en Ernst\&Young zijn ingevuld door controllers en gaan voorbij aan de vraag of andere professies in de organisatie zich de business partnerrol niet (ook) willen of kunnen toe-eigenen. En de onderzoeken gaan niet in op de vraag waarom controllers de machtsstrijd met deze groepen dan zouden kunnen winnen. Een recent onderzoek van Lambert en Sponem (2012) in een Franse context laat verschillende invullingen van de gedecentraliseerde 'management accounting function' zien. Op basis van de mate van autoriteit van de controller (laag of hoog) en wie is de belangrijkste klant van de afdeling (decentraal of centraal management) worden vier verschillende controllingafdelingen onderkend. Interessant gegeven de bovenstaande discussie over de machtsstrijd in organisaties is dat bij twee van de vier verschillende invullingen de mate van autoriteit van controllers zwak is. De controllers in deze organisaties lijken de machtsstrijd te hebben verloren. Het blijkt moeilijk om in een dergelijke afdeling invulling aan de business partnerrol te geven. In het onderstaande citaat gebruikt één van de CEO's zelfs het woord 'servile' dat slaafs betekent om de controllerfunctie te duiden.

"The CEO gathered the management accounting function together and clearly told them; 'Always keep in mind that you are a servile function'." (Lambert $\&$ Sponem, 2012, p. 573)

De onderzoekers geven aan dat juist controllers in deze organisaties over het business partnerconcept spraken als de heilige graal. Echter de operationele managers in deze organisatie hechten weinig waarde aan analyses van de controller en ze waren zeer terughoudend om de controllers te betrekken bij strategische zaken (2012, p. 573). Gegeven de machtsverhoudingen in deze organisaties is het kennelijk onmogelijk om als business partner te functioneren.

Behalve door de mate van gezag wordt de invulling ook bepaald door wie de belangrijkste klant van de controller is. De decentrale of de centrale organisatie? De belangrijkste klant relateert aan de vraag of de toezichtfunctie of de adviesfunctie in de werkzaamheden van de controller centraal staat. Als de centrale organisatie als belangrijkste klant wordt gezien dan ligt de nadruk op de controlerende rol. In de organisaties waarbij decentrale financiële targets hoog waren, functioneerde de controllingfunctie als een (business) partner van het decentrale management. Bij slechts één casusorganisatie was de voornaamste klant van de controller het hoofdkantoor en was er sprake van een hoge mate van autoriteit. In deze organisatie was de invloed dermate hoog dat er kan worden gesproken over een zeer do- minante invloed. Deze invulling kan het gevolg zijn van het aanstellen van de CFO als nieuwe CEO (Lambert \& Sponem, 2012, p. 582).

De onderzoeken van Mouritsen (1996) en Lambert en Sponem (2012) geven aan dat juist interne machtsrelaties kunnen bepalen in hoeverre controllers meer als business partner kunnen werken.

\section{Advies en onafhankelijkheid}

Lambert en Sponem geven in hun artikel ook de risico's van de verschillende stijlen aan. Bij de (business) partnerstijl worden risico's op het gebied van de vertrouwens- en toezichtsfunctie benoemd (2012, p. 581). Dit roept de vraag op in hoeverre de mate van betrokkenheid van controllers, de mate van het daadwerkelijk als business partner functioneren, niet mede wordt bepaald door de mogelijk negatieve invloed op de noodzakelijke onafhankelijkheid van de controller als bedrijfseconomisch geweten van de organisatie. Boekhoudfraudes en onregelmatigheden hebben het belang van interne controlesystemen en de rol van de controller hierin op de agenda gezet (Van de Ven 2010). De boekhoudschandalen aan het begin van de eeuw hebben de vraag opgeroepen wat de onderliggende oorzaken van de manipulaties met cijfers zijn. Feng et al. (2011) vragen zich af wat achterliggende motieven van de CFO's geweest kunnen zijn. Is het eigenbelang of is er een andere reden? Een vergelijkend onderzoek tussen organisaties waar manipulaties wel en niet zijn geconstateerd, levert geen verschillen op tussen beloningvormen van de CFO's. De CEO's van de organisaties die met de cijfers hadden geknoeid, hadden wel hogere bonussen en meer macht dan de bestuurders van de controlegroep. Er werd ook een significant hoger verloop van CFO's bij deze organisaties vastgesteld. De conclusie die Feng en collega's hieruit trekken, is dat CFO's minder uit eigen financieel belang handelen maar toegeven aan de druk van de bestuurder. In hoeverre moeten controllers businesspartner willen zijn van dergelijke bestuurders? De onafhankelijkheid van de controller is immers een belangrijk aspect van zijn controlerende verantwoordelijkheid. De boekhoudschandalen aan het begin van deze eeuw en de vele jaarrekeningen die na publicatie toch moesten worden herzien, heeft de financiële functie gedwongen meer aandacht te besteden aan de onafhankelijkheid van de controller en het bevorderen van interne controle (Davis \& McLaughlin, 2009, p. 35; Sinnett 2007). Ook de crisis van 2008/2009 betekent meer aandacht voor de betrouwbaarheid van informatie en de toezichthoudende verantwoordelijkheden (CIMA, 2009, p. 14). Rapportages worden door de nieuwe regelgeving uitgebreider en complexer en het belang van risicomanagement en handhaving van interne en externe regelgeving krijgen een belangrijke plaats in de bedrijfsvoering van organisaties. 
Een aandachtsgebied hierbij is het mogelijke rolconflict dat kan ontstaan tussen de adviserende en controlerende functie. Uit een enquête onder 112 CFO's van Fortune 1000 blijkt dat meer dan $85 \%$ van de CFO's van mening is dat er geen conflict bestaat tussen de rol van de controller als businesspartner en de noodzakelijke onafhankelijkheid voor de financiële rapportage en de interne beheersing als het gaat om de verbetering van bedrijfsresultaten (Davis en McLaughlin, 2009, p. 36). Maar het onderzoek van Maas en Matjeka (2009) laat wel zien dat een hogere mate van betrokkenheid negatieve effecten heeft. Het invullen van de adviserende rol gaat vaak gepaard met een decentrale positionering van controllers bij divisies. Als lid van het managementteam kunnen zij invulling aan de adviesrol geven en hebben zij een verantwoordelijkheid naar het lijnmanagement. Om de controlerende rol in stand te houden, onderhouden zij een functionele verantwoordelijkheid in de controllerkolom. De mate van invloed van de 'financiële baas' met betrekking tot de beoordeling, het salaris, prioriteiten in werkzaamheden, ontslag en promotie, had een effect op de mate van de onzekerheid ('role ambiquity') en op de mate van spanning tussen de beide rollen ('role conflict'). De stress als gevolg van de spanning tussen de verschillende rollen kan leiden tot disfunctioneel gedrag. Het onderzoek laat zien dat controllers ervaren dat de stress gecorreleerd is met het manipuleren van informatie in de vorm van het boeken in verkeerde perioden, het inbouwen van buffers in prestatietargets, het schuiven met budgetten en het overboeken van gelden. Met betrekking tot het inbouwen van buffers laat een experiment van Hartmann en Maas (2010) zien dat controllers die geloven dat voor het bereiken van het doel elk middel is geoorloofd (in hun woorden een hoge mate van Machiavellianism), eerder aan druk van het management toegeven.

Bij het invullen van de business partnerrol kan er spanning ontstaan tussen de vertrouwens- en de toezichtsrol van de controller. Het maar beperkt invullen van de business partnerrol kan voortvloeien uit trade-offs die worden gemaakt tussen het vervullen van de vertrouwensrol en toezichtsrol ten opzichte van het volledig vervullen van de rol als business partner.

\section{Conclusie}

De wens dat controllers business partner zouden moeten worden is zeker niet nieuw. De rolverandering van de controller gaat echter minder snel en minder extreem in de richting van waarde-creatie dan de verwachtingen en wensen van controllers en van aanbevelingen in adviesrapporten. In plaats van aan de roep toe te geven dat controllers business partners moeten worden, lijkt het wenselijk om meer aandacht te besteden aan de factoren die dit in de praktijk bemoeilijken en om de grenzen van het optreden als business partner te onderzoe- ken. Onderzoeken naar hoe controllers hun rol invullen laten een gedifferentieerd en complex beeld zien.

Zo laten de onderzoeken van Mouritsen (1996) en Lambert en Sponem (2012) verschillende mogelijke configuraties van controllership in organisaties zien, waarbij slechts in enkele configuraties de controller voldoende gezag heeft om actief deel te nemen aan de besluitvorming. Welke rol uiteindelijk tot stand komt in een organisatie is het resultaat van een interactie tussen controllers en andere professionals in de organisatie. Toekomstig onderzoek naar hoe deze machtsprocessen binnen organisaties zich afspelen kan een nog beter inzicht bieden in de aard van de barrières die controllers tegenkomen als zij meer als business partner willen functioneren.

Naast organisatorische invloeden laat wetenschappelijk onderzoek ook andere factoren zien die de rol van individuele controllers beïnvloeden. De controllerenquêtes laten zien dat er in Nederland twee verschillende typen controllers te onderkennen zijn. Implementatie van ICTsystemen, toename van wet- en regelgeving en financiële druk op een organisatie kunnen een grote invloed hebben op de wijze waarop de functie van controller wordt ingevuld. Ook meer aan de persoon gebonden factoren, zoals ervaring en persoonskenmerken lijken mede bepalend te zijn voor de wijze waarop controllers hun werkzaamheden uitvoeren. In de praktijk kunnen afwegingen worden gemaakt die leiden tot het volledig benutten van competenties van de huidige controllers en dat zou wel eens ten koste kunnen gaan van het in sterkere mate optreden als business partner.

Ook geeft onderzoek een potentieel aanwezige negatieve wisselwerking aan tussen de business partnerrol en de vertrouwens/toezichtsrol van de controller. Er is nog weinig empirisch onderzoek gedaan naar hoe exact de adviesrol en controlerende rol worden gecombineerd. Welke grenzen in dit kader aan de business partnerrol worden gesteld en welke afwegingen en trade-offs controllers in de praktijk maken is onderwerp van toekomstig onderzoek.

Het lijkt tijd om te stoppen met de oproep aan controllers om meer als business partner te opereren. Tijd om de exacte invulling van de controllerfuncties centraal te stellen en juist een invulling aan de rol te geven die rekening houdt met de specifieke omstandigheden van de organisatie, de rol die controlling kan en mag spelen in de organisatie, de persoonlijke eigenschappen van de controllers en een gezonde balans tussen de controlerende en adviesfunctie. Juist onderzoek van controllers met wetenschappers op basis van 'engaged scholarship' (Van de Ven \& Johnson, 2006; zie ook Van de Ven, 2011) kan nuttig zijn om inzicht te 
geven in hoe controllers in de complexe dagelijkse praktijk afwegingen tussen de verschillende verantwoordelijkheden maken en welke grenzen zij stellen aan het zijn van business partner.

Prof. dr. A.C.N. van de Ven RA is hoogleraar Bestuurlijke Informatieverzorging aan TiasNimbas Business School van de Universiteit van Tilburg en hoogleraar Controlling

\section{Noten}

Dit artikel is mede gebaseerd op de oratietekst van de auteur: Controller, waar zijt gij mee bezig ?!

2. Zoekinstructie op 23 december 2013 leverde 'ongeveer

\section{$97.000 .000^{\prime}$ resultaten op.}

3 Met dank aan collega Paula van Veen-Dirks Nan VeenDirks, 2012, p. 21) die dit onderzoek in haar oratie aanhaalt.
De relatie met administratieve organisatie is door collega Paula van Veen-Dirks naar voren gebracht tijdens het RACCsymposium op 7 januari 2014.

\section{Literatuur}

- Accenture (2008). The changing role of the finance organization in a multi-polar world. Accenture.

- Armstrong, S.J., Cools, E., \& Sadler-Smith, E. (2012), Role of cognitive styles in business and management: reviewing 40 years of research. International Journal of Management Reviews, 14, 238-262

- Baldsvindottir, G., Burns, J., Nørreklit, H., \& Scapens, R.W. (2013). Commentary: a business partner in the 1960s. In ICAEW (2013). Finance in the broadest sense (pp. 47-53). Londen: Finance \& Management Faculty ICAEW.

- Burns, J., \& Baldvinsdottir, G. (2005). An institutional perspective of accountants' new roles of the interplay of contradictions and praxis. European Accounting Review, 14(4), 725-757,

- Bradley-Geist, J.S., \& Landis, R.S. (2012). Homogeneity of personality in occupations and organizations: a comparison of alternative statistical tests. Journal of Business and Psychology, 27(2), 149-159.

- Briggs, S.P., Copeland, S., \& Haynes, D. (2007). Accountants for the 21st Century, where are you? A five-year study of accounting students' personality preferences. Critical Perspectives on Accounting, 18, 511-537.

- CFO Research Services (2002). CFOs: Driving finance transformation for the 21st century. CFO Research Services in collaboration with Cap Gemini Ernst\&Young, 26.

- Chui, L., \& Curtis, M.B. (2010). Intrepreneurs and Innovation - Here's a new approach to the adoption of continues monitoring. Strategic Finance, 92(5, november), 49-53.

- CIMA (2009). Improving decision making in organisations the opportunity to reinvent finance business partners. Jully 2009.

- Davis, T.R.V., \& McLaughlin, L.P. (2009). Finance partnering role (part 1). Is finance a business partner yet? Strategic Finance, 90(9), 35-40.

- De Lo0, I., Verstegen, B.H.J., \& Swagerman, D. (2011). Understanding the roles of management accountants. European Business Review, 23(3), 287-313.

- Ernst \& Young (2008). The changing role of the financial controller. Research report: Ernst \& Young.
- Ezzamel, M., \& Burns, J. (2005), Professional competition, economic value added and management control strategies. Organization Studies, 26(5), 755-777.

- Feng, M., Ge, W., Luo, S., \& Shevlin, T.J. (2011). Why do CFOs become involved in material accounting manipulations? Journal of Accounting and Economics, 51(1), 21-36.

- Harding, S.R. (1963). Increased productivity - the role of finance. In ICAEW (2013). Finance in the broadest sense (pp. 23-45). Londen: Finance \& Management Faculty ICAEW.

- Hartmann, F., \& Maas, V. (2010). Why business unit controllers create budget slack: involvement in management, social pressure, and Machiavellianism. Behavioral Reseach in Accounting, 22(2), 27-49

- IBM (2010). The new value integrator - insights from the global chief financial officer study. Somers: IBM 62.

- ICAEW (2013). Finance in the broadest sense. Londen: Finance \& Management Faculty ICAEW.

- Johnsson, M. (2002). The changing role of the CFO. Strategic Finance, 83(12), 54-67.

- Kester, R.B. (1928). The importance of the controller. The Accounting Review, 3(3), 237-251.

- Kolthof, E., \& Lemstra, S. (2008) Chief Value Officer, het lonkend perspectief voor financials - experts voorspellen toekomst vakgebied finance. Management Control \& Accounting, 13(3), 40-44.

- Lambert, C., \& Sponem, S. (2012). Roles, authority and involvement of the management accounting function: a multiple case-study perspective, European Accounting Review, 21(3), 565-589.

- Maas, V. (2005). De rol van de controller in Nederland. Management Control \& Accounting. 9(5), 16-20.

- Maas, V.S., \& MatZikja, M. (2009). Balancing the dual responsibilities of business unit controllers: Field and survey evidence. The Accounting Review, 84(4), 1233-1253.

- Merchant, K.A., \& Van der Stede, W.A. (2007). Management control systems - performance measurement, evaluation and incentives (2nd ed.). Harlow: Prentice Hall - Financial Times.

- Mouritsen, J. (1996). Five aspects of accounting depart- ments' work. Management Accounting Research, 7, 283303.

- Russell, K.A., Siegel, G.H., \& Kulesza, C.S. (1999). Counting more, counting less. Strategic Finance, 81(3), 39-44.

- Sathe, V. (1983). The controller's role in management. Organizational Dynamics, 11(3), 31-48.

- Simon, H.A., Kozometsky, G., Guetzkow, H., \& Tyndall, G. (1954). Centralization vs. decentralization in organizing the controller's department: A research study and report. Houston TX: Scholars Books Co.

- Sinnett, W.M. (2007), CFO skillsets changing... AGAIN. Financial Executive, 23(5), 35-37.

- Ven, A.C.N. van de (2010). Risk management from an accounting perspective. In M. van Daelen en C. van der Elst (eds). Risk management and corporate governance interconnections in law, accounting and tax. Cheltenham: Edward Elgar Publishing

- Ven,A.C.N. van de (2011). Controller, waar zijt gij mee bezig ?! Oratie, Heerlen: Drukkerii Open Universiteit.

- Ven, A.H. van de, \&. Johnson, P.E. (2006). Knowledge for theory and practice. Academy of Management Review, 31(4), 802-821.

- Veen-Dirks, P. van, \& De Lo0, I. (2011). Is de 'strong controller' in aantocht? Management Control \& Accounting, 16(4), 212-218.

- Veen-Dirks, P. van (2012). Management accounting informatie: een kwestie van balans? Oratie, Groningen: Drukkeri] Rijksuniversiteit Groningen

- Verstegen, B.H.J., De Loo, I., Mol, P., Slagter, K., \& Geerkens, H. (2007). Classifying controllers by activities: an exploratory study. Journal of Applied Management Accounting Research, 5(2), 9-31.

- Woerd, G. te (2009). Finance als business partner - Hoe voeg je waarde toe aan de business. Finance \& Control, 8(3, juni), 28-31.

- Zoni, L., \& Merchant, K.A. (2007). Controller involvement in management: an empirical study in large Italian corporations. Journal of Accounting \& Organizational Change, 3(1), 29-43. 